\title{
A HUNDRED YEARS OF THEOLOGICAL TRAINING IN THE APOSTOLIC FAITH MISSION OF SOUTH AFRICA
}

\section{ABSTRACT}

The AFM started as an interracial mission with a strong emphasis on the "anointing of the Holy Spirit" and the ministry of each member of the assembly. Leadership was developed through the local church as the body of Christ and there were no distinctions between clergy and laity. All who were saved were expected (and trained) to witness; no theological training was required for the different levels of ministry, not even for preachers. There was a hierarchy starting with church members being witnesses, but with the opportunity to develop into a deacon, elder, local preacher, and finally an overseer. In this article the development of training for the ministry along separate lines for different racial groups in accordance with the ruling Apartheid policy of the Nationalist government is discussed. After a hundred years the AFM has one training structure with a new centralized seminary and one curriculum for all.

\section{INTRODUCTION}

Theological training in the AFM can be divided into several periods, reflecting the changing attitudes towards training of pastors, from a period of no formal training to training arranged as a Bible School, and later as theological colleges, until training acquired a theological depth with the connection with theological faculties at universities. 


\section{PRE-BIBLE SCHOOL YEARS: $1908-1923^{1}$}

The AFM started as an interracial English-speaking mission with a strong emphasis on the anointing of the Holy Spirit (Du Plessis 1984:40). Despite the pneumatological emphasis, it took less than two years after its founding for the AFM to become mainly a segregated church (Burger 1987:422). The strong Pentecostal conviction, with its all-inclusive attitude towards those who accepted the teachings of salvation, healing, the baptism in the Holy Spirit, and the second coming of Christ (Chappell 1986:72; Dayton 1987:19-20), was not strong enough to keep the body of faith in unity. The racial and cultural differences separated the AFM into "White" and "Black" Sections, dominated by the "Whites" (Pillay 1994:191). The "Black" church was organized along the lines of Black, Coloured and Indian Sections. The embryo of later formal theological training followed suit.

In the early AFM, leadership was developed through the local church as the body of Christ (Langerman 1983:124). There were no distinctions between clergy and laity because all members were seen as priests and all who were saved were expected to witness to unbelievers (Burger 1987:181). Elders, deacons and missionaries were the equipment ministries and members who excelled in these ministries were issued with certificates (Langerman 1983:125; The Constitution of the AFM of SA, Articles 284-292). No titles were used for these ministries; everybody called each other "brother" and "sister". There was no distinction between full-time and part-time assembly leaders and at first there were only a few full-time leaders (Burger 1987:182). Calling, anointing, and application of ministry was the way in which believers came into the ministry and all members were encouraged to follow this way, and a person's ministry was only confirmed by the Certificate that the Executive Council ${ }^{2}$ issued (Van der Spuy 1985:105-106; Workers' Council Report, $73^{\text {rd }}$ Annual General Meeting, viii.) No theological training was required for any of the levels of ministry in any part of the church. There was a clear hierarchy starting with every church member as a witness, then a local preacher, deacon, elder and finally an overseer (Langerman 1983:79).

1 The information in this article is mainly condensed from Burger 1987; Erasmus 1996; Burger \& Nel 2008; and the minutes of the relevant Councils.

2 The Executive Council was responsible for the business of the AFM when the Workers' Council was not in session. The Executive Council was formed by the chairpersons of the different districts (later called regions) and the National Office Bearers elected by the Workers' Council, and the Workers' Council was constituted of representatives of all assemblies. Today the Workers' Council is called the National Business Meeting and the Executive Council is called the National Leadership Forum. 
Control over missions ${ }^{3}$ to the indigenous people of Africa was in the hands of the "White" Executive Council. The Executive Council resolved "that a White Superintendent or Superintendents be appointed by the council over the Native work in the respective colonies of South Africa, who shall act in harmony with and subject to the approval and confirmation of the Executive Council" (Minutes of the White Executive Council (MWEC) 1909:37). The non-White ${ }^{4}$ sections of the church were organized into the Missionary Committee under the leadership of the (White) Superintendent of Missions. The offices recognized in the Black work were: Local Preachers; Deacons; Elders; and Overseers. Elders and overseers were considered ministers (Khathide 2010:27).

Theological training that would develop over time in the AFM was bound to follow the policy of segregation that determined the AFM and South Africa, and the theological training of White and Black workers was planned by two different bodies (Minutes of the White Executive Council 1924:49). The Missionary Committee planned for the Blacks and the (White) Executive Council for the Whites, although even the plans of the Missionary Committee were submitted to and had to be approved by the White Executive Council.

The erection of a proper training school for Black workers as well as training classes and language studies for White missionaries were discussed by the Missionary Committee on 29 December 1917 (MBEC 1917:36). A month later it was suggested that Bible teaching for Blacks at evening classes be started in Johannesburg but there is no indication that this actually came off the ground.

Hugh Hume, the secretary of the Missionary Committee, motivated the committee to open twenty mission stations in and outside South Africa in the course of 1918. In order to achieve this, missionaries would have to be trained (MBEC 1918:59) but their training consisted only of exposure to basic language skills in Zulu and Sotho. At the Workers' Conference in 1923 the need was expressed for other aspects of training as well, including a basic knowledge of Scriptures.

Equipment for ministry was seen as a need for both Black and White workers and the format this equipment was to take on was placed in two categories: The equipping of evangelists and preachers for local churches, and that of White missionaries ministering to Blacks; the latter needed, apart from Bible knowledge, also the study of an indigenous language.

3 The AFM followed the convention of those days to distinguish between missions as preaching to Blacks and evangelism as preaching to Whites.

4 The Apartheid jargon is followed even though the sentiment is not shared. 
Because the social set-up in South Africa was racially divided, the Church saw no reason to integrate the equipping of the different races.

Theological training was not formally offered in those years and the AFM never considered a theological basis as necessary or profitable for the formation of a pastor. The Bible was used at face value and literally and pragmatically interpreted (Barr 1983:27). The need for Bible education was stressed but it was clear that this had to be (literalistic) Bible knowledge according to the understanding of the AFM and not according to the "churches", referring to other existing denominations which indicates a feeling of superiority over other churches (Nel 1993:12). The criticism of other churches over the AFM's preaching and practice of healing and the baptism in the Holy Spirit with speaking in tongues led to the AFM's antichurch attitude, and justified by viewing other churches as "dead" and "functioning without the anointing of the Holy Spirit" (Kelsey 1964:78). ${ }^{5}$ Theological education as such would have been rejected, because it sounded too much like terms that the "churches" use (Burger \& Nel 2008:141). The substitute would be "Bible training" with the emphasis on the application of the content of the Bible in the light of the theory and practice of the AFM. ${ }^{6}$

The pre-Bible School years can be described in terms of the theological theory that the local church is the "nursery" for the growth of pastors as church leaders and it dominated the way in which theological training was practiced. Academic achievement was not seen as important or necessary and spirituality as the renewing work of the Holy Spirit in the life of the believer and in the Church was emphasized. There seems to have been no tension between spirituality and academic achievement (Erasmus 1996:2542). A discussion of the earliest Bible School years will follow.

\section{EARLIEST BIBLE SCHOOL YEARS: 1929-1949}

The focus of the Bible School years was on mentoring a new generation of preachers and pastors by way of introducing them to basic Biblical training and exposure to the practical ministry.

5 In Pentecostal circles, the "anointing of the Spirit" is used as a technical term to refer to Spirit-filled Christians' effective ministry "in the power of the Spirit." Thus a pastor's ministry would be described as an anointed one if it is followed by signs and wonders, and conversions.

6 The AFM refused to be called a church, like the rest of the Pentecostal movement, and rather referred to itself as a "Mission". 


\section{1 "Black Bible school"}

Racial segregation determined the social fabric of the South African community and the fact that the Bible schools of the AFM were racially divided was the logical result of the political policy that the Church accepted unquestioningly as part of its functioning (Burger 1987:431). The racial separation was not theologically grounded, but based on an uncritical acceptance of the social practice in South Africa.

In spite of political and economic difficulties, Elias Letwaba, the Black overseer of Northern Transvaal, was able to fulfill the Bible education need among Black ministers. He was willing to begin with training without any financial guarantees. His "Black" Bible School paved the way for the development of a Pentecostal theological educational institute with its roots in Africa and his faith and determination made him the pioneer of theological education in the AFM, being the principal of the first AFM Bible School. On 3 February 1922, the Missionary Committee approved that Letwaba start a Bible school for the training of evangelists. They felt, however, that "later a central school is expected to materialize" (Erasmus 1996:25-42). This centralized school only materialized in 1950 (MWEC 1950:187). Letwaba's vision took only two years to materialize and his initiative formed the first official Bible school of the AFM.

On 24 October 1924, P.L. le Roux reported to the Executive Council that he had visited the opening of the evangelist training school in Potgietersrus "which had been built by Bro. Letwaba and other Native brethren" (MWEC 1924:48). The name of this school was the Patmos Bible School (MWEC 1926:57) and most of the lecturing was done by Letwaba with lectures in Dutch and Sotho (Burton 1934:97). In addition to the Patmos Bible School, a primary school with 150 pupils was also established next to the Bible School and some of the students in the Bible School were also employed as teachers in the primary school.

Although it was not Letwaba's vision to create a racially divided Bible school, he followed the already segregated practice of the Church without questioning it. His silence on racial matters endorsed the apartheid system.

Since the Special Conference of Workers in 1920, the matter of Bible school training for Whites was on the agenda and discussed several times (e.g., MWEC 1920:410 1921:471; 1923:654; 1926:945; etc.). To attend a Bible school was not compulsory, as was clearly stated and motivated in the words of P.L. le Roux,

Let us say right here, don't be mistaken, we do not want everybody to go to the Bible School, but when a brother has shown by his life and ministry the proof of God's calling in his life, we are prepared to 
let him enter the field without Bible School Training (Minutes of the White Workers Council (MWWC) 1926:941).

But the firm decision at the Workers' Conference in 1927 formed the basis for the establishment of a Bible School, “... that realizing the need for a Bible school, we unanimously agree that such an institution be established without delay" (MWWC 1927:964). A decisive step to establish this Bible School was however only taken at the end of 1929.

\section{2 "White Bible school"}

The second Bible school of the AFM (after Letwaba's) had a female missionary from the USA, Mrs. Henrietta Fruen, as principal. She was appointed on 20 December 1929 (MWEC 1929:1136). This marked the beginning of Bible school education for White workers of the AFM. In February 1931 full-time classes commenced with six students (MWWC 1930:2; 1931:1209). Fruen was not satisfied with her position as teacher of the Bible School and she resigned on 14 April 1930, four months after she had started; the Council did not accept the resignation (MWEC 1930:1169). Her resignation as a member of the Mission was accepted on 4 March 1932, only two years after she had begun her work as Bible teacher (MWEC 1932:1290); the reason for her resignation was that she was in doubt if it was in the mind of the Lord for her to continue the Bible School. She was disappointed with the low spiritual tone in the Mission and she felt that she did not have the "hearty co-operation of the leaders" (MWWC 1932:1297). ${ }^{7}$ With the eventual resignation of Fruen on 4 March 1932, the Bible School also came to a close. The short history of this Bible school consisted of one year of evening and one year of full-time classes.

From 1932 to 1935 only the Patmos Bible School was functioning which was exclusively for Black students and between 1932 and the middle of 1940 the AFM had no Bible school for Whites. Although it was often debated in the different Councils of the Church from 1932 to 1940, the third White Bible school of the AFM only opened in June 1940 (MMC 1935:114; MWWC 1934:1489-1491; MWEC 1940:2163). Past. Charles Bennett was the principal and his school also did not have a name. It opened in Johannesburg on 9 June 1940 with evening classes for four students in the Tabernacle, the mother church of the AFM (MWEC 1940:2220) and it closed at the end of 1947 (MWEC 1947:3076). Fruen only managed to run the day classes for one year, while Bennett led the day classes for eight

7 Perhaps chauvinism of the exclusively male leaders in the AFM led to her observation and resignation. 
years during this period and then again for a second term of fourteen years (1955-1968).

A shift occurred from the early perception that the anointing of the Holy Spirit was all that was needed to be effective in the ministry, to an understanding that Biblical education in a Bible school should be added to the experience of the "anointing of the Spirit." This does not mean that the anointing of the Holy Spirit was downgraded; it was rather an awareness of the necessity of Bible knowledge that needs to be combined with spiritual experience (Kelsey 1972:94). The fear was still expressed that Bible knowledge might lead to a "learned" ministry, which depends more on knowledge than on the Spirit. Therefore the AFM called its training institutions "Bible schools", to distinguish it from that offered by universities and seminaries for established churches. The AFM did not feel that their Bible school was of a lower standard but emphasized that it was more "spiritual," Bible-centered and -oriented with the Bible forming the main textbook (MWEC 1947:3094).

The strong anti-Church attitude was expressed in the feeling that the Bible school should not be a theological college. The idea of the AFM exercising superiority over other churches that did not experience the baptism in the Holy Spirit was reaffirmed repeatedly in this period (Burger \& Nel 2004:142).

Economical and political realities during this period influenced the Bible Schools. The depression of the early 1930's had some influence on the closure of the first two Bible schools of the AFM, as the Church was suffering financially, and financial support for both students and lecturers was lacking (Burger 1987:265-6). The third Bible school was planned in 1939, when the Second World War started, and was able to function right through the War, only closing two years after the War. The War had little influence but the rise of pro-German sentiments among some Afrikaners and Afrikaner nationalism might have had a negative influence as Bennett was an Englishman and he lectured in English. There were repeated requests that study material be made available in Afrikaans. As the private Bible correspondence course of past. Gerrie Wessels and dr. F.P. Möller introduced in 1946 was in Afrikaans, it was well-received and created negative competition for the study material offered by Bennett in English with the result that Bennett's Bible school closed the next year (MWEC 1947:3018). Even when the AFM started with its next Bible school in 1950, the Afrikaans study programs offered by Möller was preferred to that which Bennett was presenting (Erasmus 1996:43-62). 


\section{NEW INTEREST IN BIBLE SCHOOL: 1950-1969}

\section{1 "Black Bible College"}

In 1946 the AFM had purchased a farm in Brakpan to house a Bible school for Black students, but because it was in an area that was zoned for "Whites only", the farm had to be sold again (MBWC 1947:14; 1948:19; 1949:23). It was only in 1950 that a suitable farm for a Bible school at Rietfontein near Benoni was bought by the White Executive Council for this purpose (MBWC 1950:27; MWEC 1950:18). Past. E. Cooksey was the overseer of the Rand District and he started with a District Bible school which eventually led to his appointment as the principal of the Bible School for Blacks on 20 March 1950. This fifth Bible training institute, the second one for Black students of the AFM, opened in January 1951 (MWWC 1950:345; Cooksey 1957). Cooksey states that between 1951 and 1953 , that is the time when he was in charge of the Bible school, more or less 35 students completed their studies (Cooksey 1957:2). He does not indicate the duration of the course, but it is fair to assume that it was a one-year study program, implying that an average of 12 students were educated each year. In 1953 it was reported that the Bible School farm for the education of Black students was sold and that the Bible School was moving to Pretoria under new leadership (Cooksey 1957:2).

Another Bible school was established at the beginning of 1954 with past. J.R. Gschwend as principal and was called the Leratong Bible School. Eight students were initially enrolled when the school opened but thirteen students completed their studies at the end of 1954. In April 1955 Gschwend resigned as principal and past. J. Cooksey was appointed in his place.

The future of the Leratong Bible school in Pretoria was debated at the 1961 Black Workers' Conference. The place where the Bible school was located was rezoned from a "Black" to a "White" area, most probably because it was so near to other "White" areas. This implied that the Bible school had to be relocated and the Missionary Committee was urgently requested to make provision so that the Bible school could continue after 1964 (MBWC 1964:109). The relocation of the Bible school was brought to the attention of the White Executive Council with the request that they do everything possible to enable the School in Pretoria to continue (Minutes of the Missionary Committee (MMC) 1964:108), but all efforts to keep the School open in Pretoria failed. It was closed at the end of 1964 and was only reopened in 1968 at its new premises in Potgietersrus. This was the second time that the draconian Apartheid laws of the country interrupted 
the progress of theological training in the AFM; the first time was in 1946 when the Bible school farm in Brakpan had to be sold.

The theological training of Black students went into a new phase when 24 students who came from all over South Africa moved into the new buildings in Potgietersrus on 11 May 1968 (MBEC 1968:32). The name of the institute was changed from Leratong Bible School to "The AFM of SA Bantu Bible College" (Minutes of the Missionary Council 1968:126). The word "School" was replaced with "College" as in the White Section, although in the Black Section it came eighteen years later. This can be seen as an indication of the desire to lift the standard of education within the Black Section of the AFM although the duration of the study program was still limited to one year.

It is not clear whether the lower standard of education in the Black Section was still due to the decision taken at the White Workers' Conference of 1944 that as far as the education of Blacks are concerned, "the Mission stands for a lower education, but is definitely against a higher education" (De Wet 1989:170). However, the Black workers asked the Black Executive Committee in 1971 to change the one-year course at the Bantu Bible College into a three-year study program (MBWC 1970:130). This demonstrates the desire of the Black workers for an improved education. The request was only acceded to 14 years later, when the course changed into a three-year study program in 1984. This Bible College moved to Soshanguve, near Pretoria, in 1975.

\section{2 "Coloured training"}

Past. J. Gillingham started a part time Bible school for Coloureds in the Cape in 1957, with classes during the evenings. Some years later past. J.J. Louw reported to the Missionary Council on the progress of the training project in Cape Town where he was training Coloureds (MMC 1969:130) indicating that the training of Coloreds was treated separately from that of Whites and Blacks.

\section{3 "Indian training"}

Past. C.J.J. Nielsen, the overseer of the "Indian work", started a Bible school for Indians in 1957. He obtained a spacious building and a number of young Indians who felt the call of God to the ministry were in training but this School did not survive for any length of time (MMC 1957:53). 


\section{4 "White Bible College"}

The Apostolic Bible College for Whites was a correspondence school. In the words of A.J. Schoeman, General Secretary of the AFM, in February 1950, "The Mission is our classroom. Christ is our head, the Holy Spirit is our Teacher and the Bible is our main text book" (MWEC 1950:3321). With these words the new approach towards training in the AFM was introduced. Distance education was accepted as the preferred method. The education was described as "Christocentric," "Holy Spirit driven," and "Biblically based" (MWEC 1949:3282). ${ }^{8}$

This fourth Bible College of the AFM was founded by dr. F.P. Möller. After being only four years in the AFM, at the age of 27 years, he was appointed as principal of the Correspondence Bible College on 23 January 1950. His appointment resulted from one of the recommendations of the Committee on the Compilation of a Bible Correspondence Course (MWEC 1949:3283). The name of the institute was the "Apostolic Bible College" and its office was at the headquarters of the AFM, in 7 De Villiers Street in Johannesburg. The Bible College later moved along with the headquarters in 1957 to its new premises at 40 Ameshoff Street in Braamfontein.

For the first four years this was only a correspondence course for parttime students. Refresher courses for pastors ${ }^{9}$ became part of the function of this College in 1952 and it was only in 1954 that an intramural department with full-time students was added. Within a year the number of students who enrolled at the College grew to 90 , and in the space of two years this number increased to 190 . When the new intramural College opened in 1954 there were already 325 students enrolled for the correspondence course (MWWC 1954:4272).

The refresher courses were one of the activities of the Bible College under the leadership of F.P. Möller, as a way to educate pastors who were already in ministry of which the majority never attended a Bible college. It was an on-the-job training for those in the ministry and can also be seen as the first ongoing training program for pastors. The refresher courses would eventually serve as stimuli towards full-time intramural education for pastors in the ministry that had no previous training.

Racially divided theological education continued to be an endorsement of apartheid. Not only were the Whites apart, but the Blacks were

8 The term, "Holy Spirit driven," betrays the Pentecostal emphasis on the need to minister in direct dependence upon and in the power of the Spirit as the condition for an effective and powerful ministry.

9 These courses were designed to equip pastors already involved in full-time ministry. 
subdivided into "Indians," "Coloureds" and "Bantus," the latter referring to the African Blacks.

Training eventually became part and parcel of the development of the professional pastorate and the pastoral theological approach of the Church. As theological training became compulsory for the ordained ministry the gap between the "clergy" and the "laity" broadened. The standard of education was higher than in the previous period but the leaders of the AFM were still not willing to accept the term "Theological College" for their training institutions, even though training were moving in the direction of the six theological disciplines as lectured in the BD degree courses of that period.

The advantage of compulsory Bible education for entry into pastoral ministry was in the first place that the standard of pastoral ministry was potentially lifted with standardized education ensuring uniformity in doctrine and practice. The status of the Bible Colleges was elevated and more students were recruited for the Colleges which made the per capita cost of education lower, while the image of the AFM in the country also improved (Burger 1987:439). The disadvantage of compulsory education was that the AFM moved in the direction of becoming a pastors' church, where the focus is on the pastor's ministry at the cost of members' ministry (Langerman 1983:120). A danger highlighted again and again was that training might lead to a dependence on knowledge rather than the "anointing of the Spirit" (Nel 1993:37).

An interesting observation about the earliest principals of the AFM Bible Colleges is that, except for Bennett of which it is not certain, none of them ever had formal Bible College education themselves. E. Cooksey, J. Cooksey and Bennett came from the Assemblies of God in England, and Möller's contact with Pentecostal theology came through his translation of M. Pearlman's book on the Dogmatics of the Assemblies of God in the USA. Thus all four principals were to some extent influenced by the Assemblies of God.

Another observation is the lack of home-grown educators. For 22 years Bennett, originally a missionary from England, was the principal of a College with predominantly Afrikaans speaking students and J. Cooksey, also an English missionary, was the principal of a Black College. Why did "foreigners" take the lead in training? Were there no AFM born and bred leaders suitable for the task during this period like Elias Letwaba in the preceding period? It must be pointed out that theological training was still not important enough for the AFM. In the bipolar tension between academic achievement and spirituality, the AFM still felt closer to the latter (Erasmus 1996:63-86). 


\section{THEOLOGICAL COLLEGES: 1970-1996}

This period from 1970 to 1996 was characterized by important developments in the theological training of the AFM with a shift to "theological" rather than "Bible school" training.

\subsection{Last years of Apartheid: "Black training"}

The Bible College for the Black members of the AFM, the "Central Bantu Bible College of the AFM," moved from Potgietersrus to Soshanguve near Pretoria in 1975. The word "Bantu," that initially formed part of the name, was an expression that the Government used to indicate Black people, and "Central" indicated that there were other decentralized Bible colleges as well, and this was the main or centralized College of the AFM.

In 1991 the Central Bible College experienced demonstrations and student boycotts with the result that the study program was disrupted and the College had to close for some time. There was pressure from some students to include liberation theology in the syllabus, but this was refused. G.L.R. Kinnear, the principal of the College, was of the opinion that the time had come for a Black man to become the principal of the College. On his request the Black Executive Council responded by appointing a Bible College evaluation commission to evaluate all Black Bible Colleges (MBEC 1991:243). The recommendations of their preliminary report were not applied due to lack of funds but it led to greater independence of the College from White domination, with the the appointment of G. Mahlobo as rector in 1994 as the climax.

\section{2 "Coloured training"}

Past. G.S. Erasmus was appointed as the first principal of the College that opened on 5 February 1975. He served in this position for two years until the end of 1976, when he was appointed as principal of the Pan African Bible Correspondence College that later became known as the International Theological Institute. The intramural and extramural Sections of the College thus separated in 1977 with past. S.C. Spies appointed as the principal on 23 November 1976 of the Bible College. When he retired in 1982 , past. R. Kinnear took over from him stayed on in this capacity until he resigned in 1994 and past. G. Mahlobo was appointed as rector of the amalgamated Colleges of the Composite Division of the AFM.

In 1978, the matter of two Coloured students applying to study at the AFM Theological College in Auckland Park was discussed by the White Executive Council. The Council approved of their registration on condition 
that the Coloured Executive Council recommend the applications of the two students and it was made clear that theirs was an exceptional case because they had already graduated from university and because the training provided by the Coloured College was not of the same quality as that of the White College. Other Pentecostal training was not available to these students and the Council hoped that the training at Auckland Park would qualify these two students to later train their own people. A further condition was that they should get their practical training in a Coloured assembly and not amongst White members (MWEC 28 July 1978:9012). The White Curatorium, appointed by the White Workers' Council to supervise the Theological College, only decided in 1981 that Coloured students would be allowed to study at Auckland Park.

The development of a separate Bible College for "Coloureds" came in the 1970's when the Sarepta Bible College was established in Kuilsrivier near Cape Town. The Sarepta Bible College building was completed in 1968 but it was only on 21 February 1972 that full-time day classes started with past. J.J. Louw as principal. This College amalgamated with the AFM Theological College in Auckland Park in 1970 and obtained its study material from the latter. The College was given permission to use the same material as the AFM Theological College of Auckland Park but they were not allowed to depart from that material without permission as part of the control that Auckland Park established over Sarepta Bible College in 1970. Other measures of control included that J.J. Louw was appointed as principal and chairman of the Sarepta Bible College Committee by the AFM Theological College, but the "White" Theological College reserved the right to appoint the principal of the "Coloured" College. The control over its functioning included that the principal of the AFM Theological College became an ex officio member of the Sarepta Bible College Committee. The strict control lasted until a Coloured Curatorium was established in 1977, appointed by the Coloured Workers' Council, and the independence of Sarepta was demonstrated in July 1986 when J.J. Lapoorta was appointed as principal without the consent of the White Theological College.

In 1985 a new syllabus was introduced, and the two-year study program was extended to a three-year theoretical education. On 30 June 1986 Louw withdrew as principal and past. J.J. Lapoorta took over. Lapoorta continued upgrading the College by further developing the new three-year pastoral study program and finalizing the negotiations with the University of the Western Cape to present graduate studies. In 1987 a degree program was introduced through the University of the Western Cape and students used this opportunity to obtain a degree in theology.

The Senate of the University of South Africa decided on 19 October 1995 that matriculated students with a Licentiate in Theology from Sarepta 
Theological College would be allowed to the Honors BTh degree of the University (Burger \& Nel, 2008:399). This was a breakthrough for the College, as graduates were now given the opportunity to further their studies at University level.

\section{3 "Indian training of pastors"}

After a long period of no theological training for the Indian Section of the AFM, W.L. Wilson had the vision to start a Bible College in Durban. The establishment of Covenant Bible College in 1983 was the fulfillment of a dream for the "Indian" Section of the AFM. By 1992, according to Reddy (1992:160), the Indian Section of the AFM consisted of 6500 members. Although this Section of the Church was much smaller than the other Sections, they felt the need to have their own Bible College. It started with eight students and grew to 48 day class and 85 evening class students by 1993 (Chinnappan 1993:4). From 1983 to the end of 1992 the College had 93 graduates. The College moved to 922 Umbilo Road in Durban in 1985.

\section{4 "White training"}

In 1970 the name of the "White" Apostolic Bible College was changed to the AFM Theological College (MWEC 1969:7618), and the College also changed its principal, main language, duration of the course, content of courses, approach (from a "Bible school" model to proper theological training) and location. This was the only training institute for White members of the AFM, the Apostolic Faith Mission Theological College (AFMTC) in Auckland Park in Johannesburg. The name was changed in 1997 to Auckland Park Theological Seminary (ATS). ${ }^{10}$ Past. F.H.J. Cronje took over as principal from Bennett in 1969, introducing a new direction as far as theological training in the AFM is concerned. The College was now an Afrikaans medium educational institute, mainly due to the fact that the new principal and most of the students were Afrikaans-speaking. When the College tried to open an English Section of the College in the 1980's, it was a dismal failure due to its established Afrikaans ethos. The twoyear theoretical combined with a one-year practical training changed into a three-year theoretical course. The probation year was detached from the theoretical education and students completing their theoretical education received diplomas and were legitimated before they started with their probation. At completion of a one year probation they were ordained.

In 1993 the College reached an agreement with the Rand Afrikaans University (today's University of Johannesburg) to present their degrees

http://www.afmtc.org/history, accessed 2014-04-25. 
(Burger \& Nel, 2008:400). The study program changed to a four year period. In the first three years students study towards the BA degree and in the fourth year they do an Honors degree. Students who do not qualify for enrollment as university students do a four-year diploma, or if they are above 25 years of age, a three-year diploma (MWEC 1969:7618; Burger \& Nel, 2008:400). The agreement with the Rand Afrikaans University opened the door for postgraduate studies.

\subsection{On the way to unification of the AFM and its training institutes}

This last period of twenty-six years marked the greatest changes in the theory and practice of theological training in the AFM at the time when the fall of apartheid was followed by the Church. The Church had neglected its prophetic function by developing separate Colleges for all racial groups, a sign that the Church accepted the separate development ideology. When this ideology failed politically, the Church changed its strategy and became a follower of the new ideology of national unity. The structural racial unity process in the AFM took 22 years from the time of the first move in the direction of unity, until the point was reached where structural unity became a reality in 1996.

In 1976, the principals of the various "non-White" Bible Colleges were still White "missionaries." Past. W.L. Wilson was the principal in Rhodesia, past. G.S. Erasmus at Central Bible College, past. J.J. Louw at the Coloured College in the Cape, past. R. Franz in Lesotho and past. B. Ewert in Zambia. The Central Missionary Committee also consisted exclusively of Whites, with pastors C. Nielsen, S.C. Spies, W.L. Wilson, G.S. Erasmus and J.J. Louw (MWEC 20 May 1976:8623).

In the White Section an Institute for Church Growth and Leadership was established. It presented courses for members on the study of the Bible, ministries, church growth, soul winning, orientation of new members, healing and counseling, liturgy and the working of the Spirit, and marriage counseling and enrichment (MWEC 24 May 1983:44-5, Resolution 326). The Institute was managed by dr. J. Engelbrecht with past. J.A. Wort as secretary. A Council for Church Therapy was also established with the task to compile courses for members about the healing ministry. Dr. F.P. Möller, pastors J.F. le Roux and D. Bakker wrote the courses (MWEC 24 May 1983:45, Resolution 327).

By 1985 the General Missionary Council declared that "the AFM rejects apartheid and believes in the formation of one AFM for all racial groups" (Minutes of the General Missionary Council 31 July 1985:2), a watershed 
decision indicating that the White Church had finally decided to unite with all other racial groups. The Black Executive Council decided in 1985 that "negotiations between the White and Black Sections be arranged to discuss the creation of one Constitution for all Sections" (MBEC1985:26). On 2 August 1985 the White, Black, Coloured and Indian Sections of the Church drew up a Declaration of Intent towards Unity. The document formed the basis of all future actions in the unity process and reads:

that the AFM confirms its acceptance of the Biblical principles of unity;

- $\quad$ rejects the system of apartheid based on racial discrimination as a principle in the Kingdom of God and within the structure of the Church;

- accepts the principle that the Church should operate as a single structural unit based on the above principles;

- $\quad$ and agrees that worship and membership of the Church should be based on the spontaneous grouping of believers (MBEC 1986:57-58).

- In 1990 an interim Constitution was accepted and the process towards unity was taken a step forward (MBEC 1990:219).

The White Section delayed the unity process and the Black, Coloured and Indian Sections decided in 1992 to unite in the meantime, leading to the formation of a Composite Division of the AFM. The Composite Division agreed to have only one theological institute, at the premises of the Central Bible College as the most suitable accommodation for the newly formed AFM of SA Theological Institute, and that the campuses in Durban and Kuilsrivier would be satellites (as reported in MWEC 1987:853, Resolution 87/20.3).

\section{UNIFIED AT LAST: PENTECOSTAL THEOLOGICAL SEMINARY ${ }^{11}$}

The process of total structural unity in the AFM took place on 3 April 1996. Dialogue between the theological institutions to unite was also on the agenda and it was decided in principle that there would be only one theological institute for the AFM, with satellites linked to it. The proposed structural unity was seen as a demonstration of the unity within the body of Christ, irrespective of race or social status.

11 Interview with dr. V. Atterbury, executive director of the Directorate of Education and Training of the AFM, established in 2007 to head the unified Pentecostal Theological Seminary, on 14 November 2007. 
The newly formed Executive Council of the united AFM (called the National Leadership Forum, NLF) resolved that the different regions, departments and theological training institutions, as formed under the old apartheid regime, must embark on a process of unification to be completed as soon as possible. Unification on all levels except theological training had been achieved by the time that the AFM adopted a new Constitution for the one united AFM at the Workers' Council of 1999.

The new Constitution stipulates that it is the responsibility of the NLF to

be the guardian of ministerial training, determine curricula, set minimum training requirements for entry to the ministry, accredit training institutions and evaluate the final training product (4.1.3 of the Constitution of the AFM of SA).

All attempts with regard to the unification of the theological institutions were however unsuccessful and the unification of theological training institutes was perused as a matter of high priority. The Constitution provided footage for the co-existing of the training institutions so that they could continue business while they pursue unification. The NLF meeting of November 2005 resolved that at their next meeting in March 2006 one day should be set apart for discussions on theological training within the AFM as a response to the resolution of the General Business Meeting of 2005 that the National Leadership Forum

be tasked with the unification of Theological Training Institutions by no later than 31 December 2007 given the legal and constitutional requirements (Putter 2010:1).

At their November 2006 meeting the National Leadership Forum established a new Directorate for Education and Training and in July/ August 2007 it approved a new curriculum framework to be registered with the authorities for implementation in January 2009 when the new training institution for the AFM was to be established. By the time the AFM celebrated its centenary it has one training structure, the Pentecostal Theological Seminary, with one new curriculum for all of its members. ${ }^{12}$

\section{BIBLIOGRAPHY}

BARR, J.

1983. Holy Scripture. Canon authority criticism. Oxford: Clarendon.

12 In the course of 2009 Auckland Park Theological Seminary (ATS) seceded from the unified theological institute, and this led to a court case which is still pending. 
BURGER, I.S.V.D.M. 1987. Geloofsgeskiedenis van die Apostoliese Geloofsending van Suid-Afrika 1908-1958. Johannesburg: Evangelie Uitgewers.

BURger, I. \& NeL, M. 2008. The fire falls in Africa. A history of the Apostolic Faith Mission of South Africa. Vereeniging: CUM.

BURTON, W.F.P. 1934. When God makes a pastor. London: Victoria.

Chappell, P.G. 1986. The birth of the divine healing movement in America. In: P.G. R. De Villiers (ed.). Healing in the name of God (Pretoria: Unisa), pp. 60-77.

Chinnapan, $\mathrm{M}$. 1993. In Covenant Bible College. Brochure, 1983-1993. Durban.

COOKSEY, E. 1957. Letter to M.J. van Rensburg, 1 October. AFM Archives.

DaYTon, D.W. 1987. Theological roots of Pentecostalism. Peabody: Hendrickson.

DE WET, C.R. 1989. The Apostolic Faith Mission in Africa: 1908-1980. A case study in church growth in a segregated society. Unpublished PhD Thesis. Capetown: University of Cape Town.

Du Plessis, L. 1984. Pinkster Panorama. ' $n$ Geskiedenis van die Volle Evangelie-Kerk van God in Suidelike Afrika. Irene: VEK.

ERASMUS, L.J. 1996. Theological education in the Apostolic Faith Mission of South Africa. Unpublished DTh disertation. Pretoria: University of South Africa.

KeLSEY, M.T. 1964. Tongue speaking. An experiment in spiritual experience. London: Hodder and Stoughton.

1972. Encounter with God. A theology of Christian experience. New York: Paulist.

KHATHIDE, A.G.

2010. What a giant of faith. The story of Richard Ngidi's ministry of miracles. Second edition. Kempton Park: AcadSA.

LANGERMAN, J.L.

1983. Apostolic Faith Mission of South Africa: A revitalization of the theological concepts of church ministry. Unpublished DMin dissertation. Paseda, California: Fuller Theological Seminary. 
Minutes Of The Black Executive Council. 1917; 1918; 1968; 1985; 1990; 1991.

Minutes Of The Black Workers Council. 1947; 1948; 1949; 1950; 1964; 1970.

Minutes Of The Mission Committee. 1935; 1957; 1964; 1969.

Minutes Of The White Executive Council. 1909; 1920; 1923; 1924; 1926; 1927; 1929; 1930; 1932; 1940; 1947; 1949; 1950; 1969; 1976; 1978; 1983; 1987.

Minutes Of The White Workers Council. 1926; 1927; 1930; 1931; 1932; 1934; 1935; 1936; 1939; 1950; 1954.

NEL, M. 1993. ' $n$ Man deur God in 'n hoek gedryf. Johannesburg: John G Lake Stigting.

PILLAY, G.J. 1994. Christianity in the years before union. In: J.W. Hofmeyr. \& G.J. Pillay (eds.). A history of Christianity in South Africa. (Pretoria: HAUM Tertiary), Vol. 1, pp. 172-199.

PutTer, A.P.J. 2010. Teologiese opleiding in die AGS-kerk: Verkennende en ontwikkelende beskouings vir die nuwe millennium. HTS Teologiese Studies/Theological Studies 66(1), Art. \#768, 9 pages. DOI: 10.4102/hts.v66i1.768, pp. 1-9.

REDDY, D.C.

1992. The Apostolic Faith Mission of South Africa with special reference to its rise and development in the "Indian" community. Unpublished MTh dissertation. Durban: University of Durban-Westville.

VAN DeR SPUY, M.A. 1985. Die spanning tussen vryheid en formalisering ten opsigte van die liturgiese verskuiwinge binne die Apostoliese Geloof Sending van Suid-Afrika. Ongepublikseerde MTh-verhandeling. Pretoria: Universiteit van Suid-Afrika.

\section{KEY WORDS}

Theological training

Bible school

Distinction clergy and laity

Academic achievement vs spirituality

\section{TREFWOORDE}

Teologiese opleiding

Bybelskool

Onderskeid pastore en leke

Akademiese prestasie vs spiritualiteit 